\title{
Business cycle synchronization between United States and African region: Some empirical evidence
}

\author{
Olfa Manai Daboussi ${ }^{1}$, Amira Majoul $^{2}$ \\ ${ }^{1}$ MASE- ESSAI and MACMA- TUNIS, Higher Institute of Management of Tunis, University of Tunis, Tunisia \\ ${ }^{2}$ Applied Quantitative Analysis Unit (UAQUAP) -Tunisia ISG and GATE (UMR 5824 CNRS), Higher Institute of Management of Tunis, \\ University of Tunis, Tunisia
}

Email address:

manaolfa@yahoo.com (O. M. Daboussi),majoul_amira@hotmail.com (A. Majoul)

\section{To cite this article:}

Olfa Manai Daboussi, Amira Majoul. Business Cycle Synchronization between United States and African Region: Some Empirical Evidence. Journal of World Economic Research. Special Issue: Issues and Challenges of the Financial and Economic Crisis Throughout the World. Vol. 3, No. 6-1, 2014, pp. 39-47. doi: 10.11648/j.jwer.s.2014030601.16

\begin{abstract}
This article analyzes the transmission cycle of the United States to emerging markets of the Middle East and North Africa. The related empirical literature dedicated to the transmissions of financial and real shocks on business cycles in emerging African countries does not lead to firm conclusion. We propose a different empirical approach allowing unlike previous studies to analyze how the real and financial shocks are transmitted from the United States to the region of Africa. Based on a new econometric approach in terms of Global VAR model this paper attempts to study the effect of shocks from the United States on the Middle East and North Africa countries, considering the crucial role of trade integration in the integration process in the region of Africa. The model has the advantage of conducting empirical investigations of a large number of countries. The GVAR is estimated for 32 countries over the period 1980-2013. From the functions of impulsive responses generated by this model, our results show the presence of a significant transfer of real and financial shocks of the United States to emerging countries of Africa. This result confirms the idea that a recession affecting the United States tends to affect emerging economies of Africa and even up to cause a recession in the latter.
\end{abstract}

Keywords: Business Cycle Synchronization, International Mechanism of Transmission, Subprime Crisis, GVAR

\section{Introduction}

In recent decades, the emerging countries have followed a deepened economic integration process on commodity markets and financial markets. On the one hand, trade intensified by the increase of trade agreements and the reduction of barriers to trade. In 2007, they accounted for $32 \%$ of GDP. On the other hand, financial liberalization has increased in the privatization of banks and financial institutions, and perfect capital mobility. The dissemination of this liberalization has allowed these countries to access foreign capital markets and create significant funding sources.

However, this process exposes more and more these economies to international economic trends to the extent that international integration tends to favor the rapid transmission of shocks. Thus, one can expect a change in supply and demand of goods, price developments in the international market and a sudden stop of capital will have very serious consequences for those countries.
The Asian crisis of 1997-1998 may be an example. It should at the same time reflect the fact that the process of integration has promoted the economic development of these countries.

In fact, during the $90 \mathrm{~s}$, these countries have experienced rapid economic growth, much higher than that of developed countries and constituted foreign exchange reserves that can that can cushion the shock.

The objective of this work is to study the interdependence between the United States and Africa region in particular Tunisia, Egypt, Morocco and South Africa. This is specifically empirically quantifying contemporary impacts of external shocks and to predict future effects of shocks from the United States on these countries.

Several empirical studies have attempted to address this issue. These studies are based on simple methods that involve measuring the correlation between these countries and on 
more sophisticated models using VAR models and factor models.

The drawback of these models is that the former does not allow us to study several transmission channels while the latter face a problem of identifying factors level.

In this context, we propose a relatively new approach to study the mechanisms of transmission of shocks based on global VAR (GVAR) proposed by Pesaran, Schuermann and Weiner (2004) and developed by Dees, Di Mauro, Pesaran and Smith (2007). Thus, based on this model, this study aims to assess the sensitivity of African economies to external shocks emanating from the United States. We seek to analyze how real and financial shocks are transmitted. We seek to measure the speed with which these shocks affect these economies and to identify the most vulnerable macroeconomic variables.

The remainder of this paper is well organized. First section presents the international transmission mechanism of business cycles. The second section presents our methodology to study the international transmission of shocks from the United States on the African region. Section three reports the results of the simulation. Finally we conclude.

\section{International Mechanism of Transmission of Business Cycle: Financial and Trade Links between North Africa and the United States}

Over the past two decades, emerging countries have taken important steps to promote trade openness. This was reflected by the increase in export flows, especially after 2002. Thus, as the graph 1 show, in 2007, exports from emerging countries exceeded $30 \%$ of GDP. Growth was particularly important in Asian countries: their exports and accounted for 38\% of GDP in 2007, against 24\% in 1990.

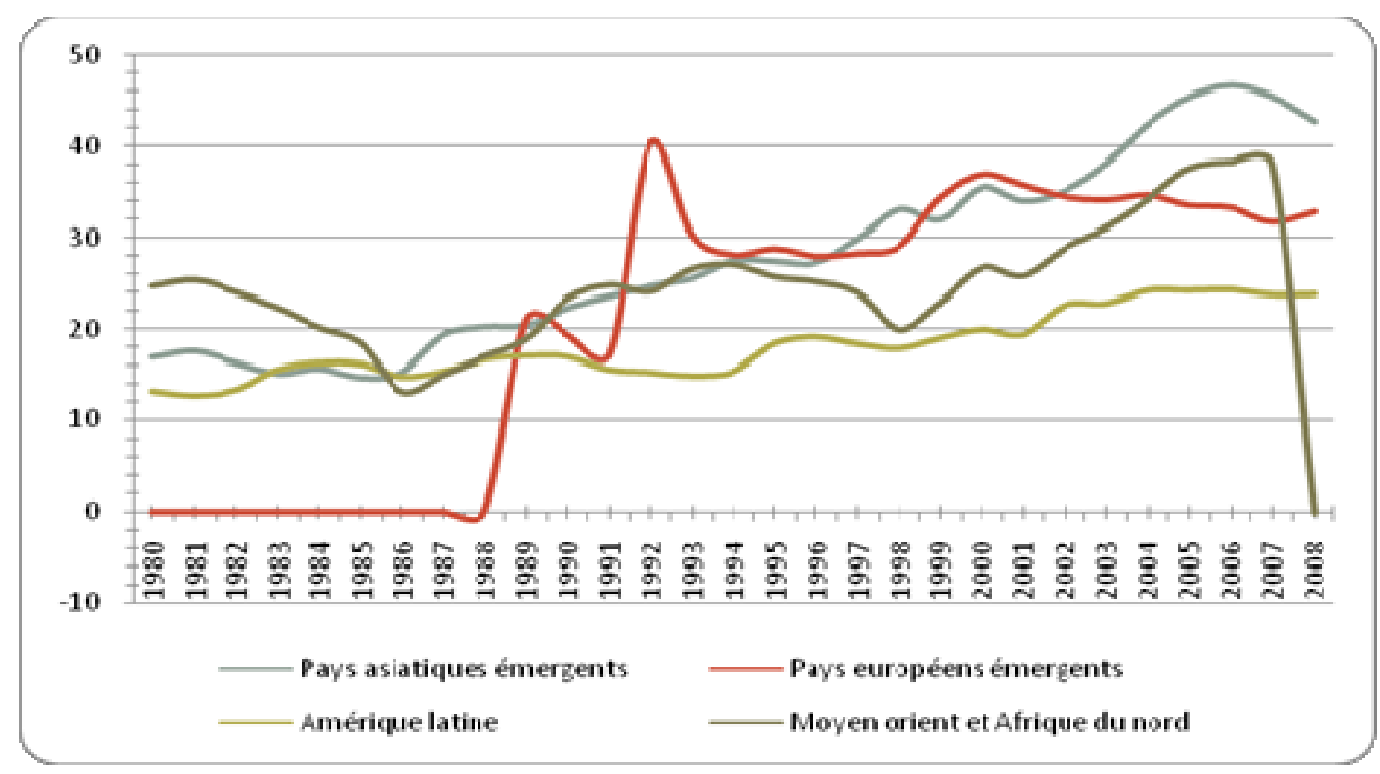

Source: Autor's caculation-WB, World developement indicators.

Graph 1. Total exports from the Middle East and North Africa as a percentage of GDP

Trade in these countries is primarily directed at developed countries. In 2007 , they represented $10 \%$ of total oriented United States exports. The weight of the United States tends to be higher than in the Euro area and Japan, suggesting a particularly strong influence of the American economy on exports from these countries.

It should be noted however that the Euro Area and Japan have close trade relations with neighboring emerging regions.

However, as the graph 2 shows, the share of the United States in total exports from developing countries has declined over time, and in all regions. Along with this relative decline, there is a geographical diversification of exports. Indeed, a growing share of exports is now facing other emerging and developing countries, especially China.

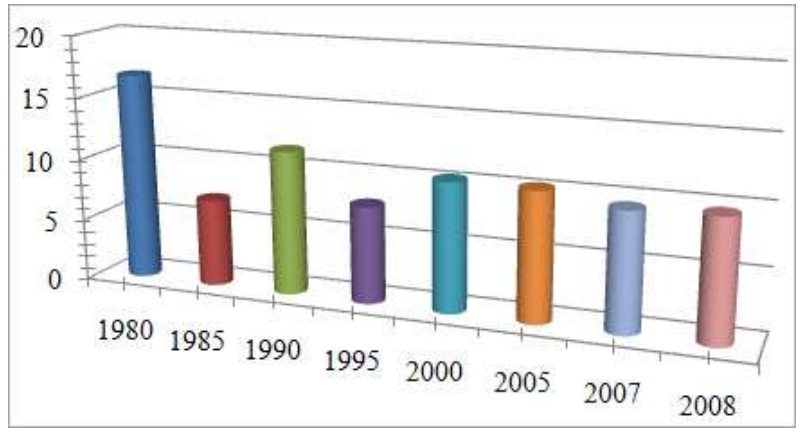

Source : Autor's calculation- IMF, Direction of trade statistics.

Graph 2. Exports of the Middle East and North Africa to the United States as \% of total exports 


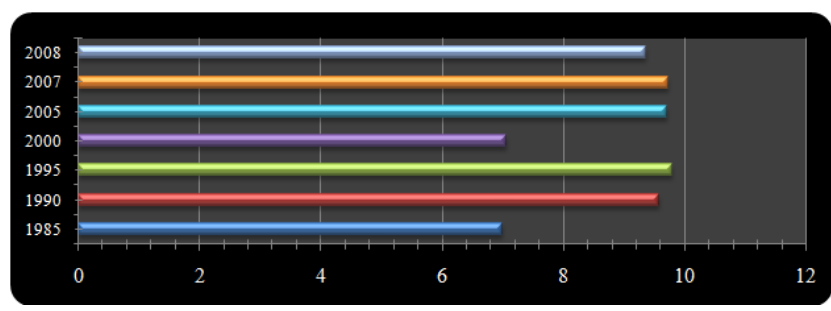

Source : Autor's calculation- IMF, Direction of trade statistics.

Graph 3. Intra-regional exports of the Middle East and North Africa as \% of total exports

In this respect, international shocks can be transmitted through the financial channel. Indeed, the opening of emerging economies to international capital markets has increased in recent decades. It resulted in a free flow of capital between countries. In this context, foreign direct investment reached $26.41 \%$ of GDP over the period 20032007 against $16.68 \%$ of GDP over the period 1990-1996.

This development owes much to various program of privatization in this group of emerging countries. FDI is generally considered an important resource-providing technology and expertise and contribute to sustainable development in economic growth.

Portfolio investments also increased significantly, especially after the Asian crisis. Indeed, the shareholding countries of the Middle East and North Africa by foreigners increased from $2.16 \%$ of GDP in $1990-96$ to $9.34 \%$ of GDP in 2003-2007.

This increase is due to the willingness of investors to take advantage of international diversification and the opportunities available to them to access these low cost markets and benefit from the higher rate of return.

Despite different nationalities of foreign investors, American investors play a leading role in the development of financial markets. They hold very high shares in the portfolios of countries in the Middle East and North Africa.

Thus, as shown in graph 4, in 2007, they hold 14\% of GDP in the portfolio of Africa. On the other hand, since 2000, many emerging countries have become investors in advanced and emerging economies, particularly exporters of oil.

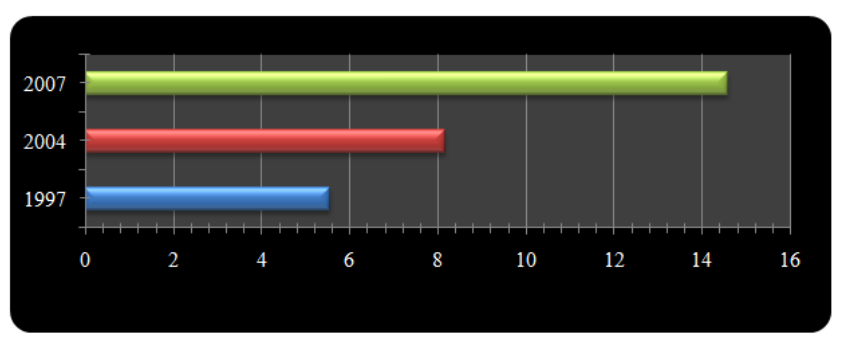

Source: Autor's calculation - Coordinated Portfolio Investment Survey- IMF. (*) North Africa includes: Tunisia, Egypt and South Africa.

Graph 4. Investment from the United States in the portfolios of North Africa as $\%$ of $G D P$

Specifically, private capital outflows in the form of direct investment in the region of Middle East and North Africa rose from $5.78 \%$ of GDP (average 1990-1996) to $10.43 \%$ of GDP (average between 2003-2007). A similar trend can be seen in private capital outflows in the form of investment portfolios.

Table 1. Commitments and assets held by the region of the Middle East and North Africa as \% of GDP

\begin{tabular}{|c|c|c|c|c|c|c|}
\hline & & & 1980-1990 & 1990-1996 & 1997-2002 & 2003-2007 \\
\hline \multirow{4}{*}{$\begin{array}{l}\text { Region of Middle East } \\
\text { and North Africa }\end{array}$} & \multirow{2}{*}{ Commitments } & FDI & 15,52 & 16,68 & 20,44 & 26,41 \\
\hline & & Investment portfolios & 1,23 & 2,16 & 4,72 & 9,34 \\
\hline & \multirow{2}{*}{ Assets held } & FDI & 3,61 & 5,78 & 7,05 & 10,43 \\
\hline & & Investment portfolios & 6,61 & 14,18 & 26,86 & 28,11 \\
\hline
\end{tabular}

Source : Autor's calculation- Lane et Milesi-Ferretti (2007).

Through this analysis, economists suggest that the relationship between the developed and emerging countries has changed over time. A rapid increase in trade and financial linkages observed between the emerging countries of Africa which suggests that these economies are more vulnerable to external shocks, particularly those in provenance of United States.

A cet égard, L'étude de la transmission des chocs a fait l'objet de nombreux travaux empiriques. L'ouverture économique et l'intégration financière ont conduit à une diversification des canaux de transmission des cycles. This transmission can be observed due to global shocks, unobserved factors (such as technological progress) or country specific shocks.

The first empirical work of Frankel and Rose (1998) studied the role of integration in the synchronization of the business cycle in developed countries. The two economists, using panel data from 20 industrialized countries over 30 years, found a positive relationship between the intensification of bilateral trade and the correlation of the business cycle.

Based on the model of Frankel and Rose (1998), Clark and van Wincoop (2001), Otto, Voss and Willard (2001), Calderon, Chong, and Stein (2002), Baxter and Kouparitsas (2004) argue that trade is the main factor that determines the degree of synchronization of the business cycle.

In the same context, Selover (1999) studied the transmission cycles between Asian countries (Indonesia, Malaysia, Singapore and Thailand) on one side and between these countries and their major trading partners of the other (United States, Australia, Japan and the European Union). He uses for this purpose component analysis, the VAR model and spectral analysis.

Binomial VAR are used to examine the relative impact of 
each country on their partners. This study shows little evidence of transmission cycles between these economies and between economies and their trading partners.

In other studies the carried out by the IMF (2007), using panel regressions, the SVAR model and the dynamic factors in a sample of 130 developed and developing countries, shows that despite the synchronization between cycles decreased over time, the role of the United States in the transmission cycles of other countries is especially important for neighboring countries. It also shows the importance of regional shocks by comparing the domestic factors and external shocks in volatility cycles. Then, Thiaw and Sene (2009) used the GVAR model to study the effect of the current crisis, on a developing economy, Senegal. They show that the negative shocks from major rich countries affected have little impact on national aggregates such as foreign aid, foreign direct investment, GDP and transfers that are supposed to be most at risk.

In general, most recent research is based on the dynamic factor model and VAR models to examine the relationships between countries. However, VAR models cannot study a large number of transmission channels simultaneously. They can indeed introduce a limited number of variables. Factor models (Stock and Watson (1998, 2002), Forni, Hallin, Lippi and Reichlin (2000) and Kapetanios and Marcellino (2003), despite their interest in terms of forecasting and number of variables studied, pose a problem in identifying factors especially when it comes to give them an economic interpretation and the elimination of the interdependence between residues due to contagion effects of trade.

In this context, the GVAR model proposed by Pesaran, Schuermann and Weiner (2004, PSW) overcomes the limitations of the models developed previously. Indeed, by integrating a large number of countries, it takes into account the interdependence of a transparent aggregate. This model can be viewed as a generalization of global macroeconomic models.

\section{The Model Structure and Estimations}

Patterns for co-movements, for the study of economic cycles between countries, have become more pronounced over the past two decades owing to increased economic and financial integration, with important implications for macroeconomic policy spillovers across countries.

To investigate the mechanisms of transmission of shocks globally, we propose a relatively new approach based on global VAR (GVAR) proposed by Pesaran, Schuermann and Weiner (2004) and developed by Dees, Di Mauro, Pesaran and Smith (2007). The originality of this model is that it takes account of global interdependence in a transparent manner by integrating a large number of countries. It also takes into account of the international transmission mechanisms channels.

\subsection{Structural of Global VAR (GVAR) Framework}

In practice, it is assumed that there are $\mathrm{N}+1$ countries (regions) in the global economy, indexed by $\mathrm{i}=0,1,2, \ldots \mathrm{N}$. « Country $0 »$ is adopted as the reference country (the United States in this study. For each country (region), it is assumed that the country-specific variables are connected by the global economic variables by $\operatorname{VARX} *\left(\mathrm{p}_{\mathrm{i}}, \mathrm{q}_{\mathrm{i}}\right)$ model as follows:

$$
\Phi_{i}\left(L, p_{i}\right) x_{i t}=a_{i 0}+a_{i 1} t+\gamma_{i}\left(L, q_{i}\right) d_{t}+\Lambda_{i}\left(L, q_{i}\right) x_{i t}^{*}+u_{i t}
$$

With $\mathrm{x}_{\mathrm{it}}$ the vector of variables to model dimension $\mathrm{k}_{\mathrm{i}} \times 1$; $d_{t}$ vector common to all countries like for example the international oil price variables; $x_{i t}^{*}$ the vector of foreign variables specific to country $\mathrm{i}$ of dimension $\mathrm{k}_{\mathrm{i}}^{*} \times 1 ; \Phi_{\mathrm{i}}\left(\mathrm{L}, \mathrm{p}_{\mathrm{i}}\right)$ and $\Lambda \mathrm{i}\left(\mathrm{L}, \mathrm{q}_{\mathrm{i}}\right)$ are polynomial matrices of dimensions $\mathrm{k}_{\mathrm{i}} \times \mathrm{k}_{\mathrm{i}}$ and $\mathrm{k}_{\mathrm{i}} \times \mathrm{k}_{\mathrm{i}}{ }_{\mathrm{i}}$ with the lag $(\mathrm{L})$ and represent the coefficients of the variables in the domestic and foreign countries respectively; $\mathrm{a}_{\mathrm{i} 0}$ and $\mathrm{a}_{\mathrm{i} 1}$ are vectors of dimension $\mathrm{k}_{\mathrm{i}} \times 1$ coefficients of variables trend. $\gamma_{\mathrm{i}}\left(\mathrm{L}, \mathrm{q}_{\mathrm{i}}\right)$, dimension $\mathrm{k}_{\mathrm{i}} \times \mathrm{k}_{\mathrm{d}}$, matrix polynomial coefficients of international variables $d_{t}$; $\mathrm{u}_{\mathrm{it}}$ of dimension $\mathrm{k}_{\mathrm{i}} \times 1$, the vector of idiosyncratic shocks specific to the country. It is assumed that the idiosyncratic shocks $\mathrm{u}_{\mathrm{it}}$ are uncorrelated with mean 0 and matrix nonsingular covariance: $u_{i t} \approx i i d\left(0, \sum_{i i}\right)$. Specific foreign country variables $x_{i t}^{*}$ are constructed from weighted averages of the corresponding relative to other countries variables. They measure the impact of trade partners on the economy in question. These variables are obtained as follows: $x_{i t}^{*}=\sum_{j=0}^{N} \omega_{i j} x_{j t}$, when $\omega_{i i}=0 . \omega_{i j}$ represents the share of country $\mathrm{j}$ in the trade (Exports + Imports/ Total of trade) of country $i$.

After selecting the lag $\mathrm{p}_{\mathrm{i}}$ and $\mathrm{q}_{\mathrm{i}}$ in each country by the AIC (assuming 2 as maximum lag), we estimate the models VARX* separately for each country for the possibility of cointegration between $\mathrm{x}_{\mathrm{it}}, x_{i t}^{*}$ and $\mathrm{d}_{\mathrm{t}}$. Once the countryspecific models estimated, all endogenous variables in the global economy are collected together in a vector $x_{t}=\left(x^{\prime}{ }_{0 t}\right.$, $\left.\mathrm{x}_{1 \mathrm{t}}, \ldots, \mathrm{x}_{\mathrm{N} \mathrm{t}}\right)$ with: $k=\sum_{i=0}^{N} k_{i}$ that represents the number of variables in the endogenous global model. For this, the model VARX * can be rewritten as follows:

$$
A_{i}\left(L, p_{i}, q_{i}\right) z_{i t}=\varphi_{i t} \text { for }(\mathrm{i}=0,1,2, \ldots, \mathrm{N})
$$

$$
\begin{gathered}
\text { Where } A_{i}\left(L, p_{i}, q_{i}\right)=\left[\phi_{i}\left(L, p_{i}\right),-\Lambda_{i}\left(L, q_{i}\right)\right], z_{i t}=\left(\begin{array}{c}
x_{i t} \\
x_{i t}^{*}
\end{array}\right), \\
\varphi_{i t}=a_{i 0}+a_{i 1} t+\gamma_{i}\left(L, q_{i}\right) d_{t}+u_{i t}
\end{gathered}
$$

Let $p=\max \left(p_{0}, p_{1}, \ldots, p_{N}, q_{0}, q_{1}, \ldots, q_{N}\right)$, and construct $A_{i}$ $(\mathrm{L}, \mathrm{p})$ from $\mathrm{Ai}\left(\mathrm{L}, \mathrm{p}_{\mathrm{i}}, \mathrm{q}_{\mathrm{i}}\right)$. Also note that:

$$
z_{i t}=W_{i} x_{t}, \mathrm{i}=0,1,2 \ldots, \mathrm{N}
$$


With $\mathrm{W}_{\mathrm{i}}$ is a $\left(\mathrm{k}_{\mathrm{i}}+\mathrm{k}_{\mathrm{i}}{ }_{\mathrm{i}}\right) \times \mathrm{k}$ matrix defined by the country

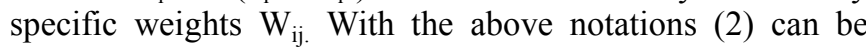
written equivalently as: $\mathrm{Ai}(\mathrm{L}, \mathrm{p}) W_{i} x_{t}=\varphi_{i t}, \mathrm{i}=0,1, \ldots, \mathrm{N}$, and then stacked to yield the $\operatorname{VAR}(\mathrm{p})$ model in $\mathrm{x}_{\mathrm{t}}$ :

$$
\text { The GVAR is as follows: } G(L, p) x_{t}=\varphi_{t}
$$

\subsection{Specification and Estimation of the Country-Specific Models}

\subsubsection{Dataset}

The proposed model takes into account 32 countries, including 28 countries, the US, China, Japan and the UK and 28 countries aggregated into regions covering the period 1980-2013 with quarterly data (see table A in appendix). The GVAR model includes the following variables: the real output1, the rate of inflation2, the exchange rate in terms of US dollars3, real equity prices 4 , the short interest rates5, the long interest rates 6 and oil prices.

These data are all collected on the website of the International Monetary Fund and from International Financial Statistics. For countries where GDP is available only annually, we proceeded to the method of interpolation used by Dees et al (2007), we estimated the GVAR model using the Gauss Program.

\subsubsection{Estimation and GVAR Model Specification}

To estimate the country specific models we have carried out preliminary tests such as tests of stationarity (ADF test and test WS) and the exogeneity test (Johansen (1992) and Harbo and al. (1998)). We noticed that introduced endogenous and exogenous variables are integrated of order 1. The assumption of weak exogeneity is not rejected for most variables confirming the hypothesis of weak exogeneity. Indeed, we found only 7 cases out of 159 cases are significant at the $5 \%$ level 7 .

As we said the key to our strategy is the weak exogeneity assumption of $\mathrm{x}^{*}$ it. This test involves testing the significance of estimating the error correction term in the auxiliary equation of variables specific of foreign countries, $x_{i t}{ }_{i t}$. In particular, each $1^{\text {th }}$ element of $\mathrm{x}^{*}$ it the following regression is carried out:

$$
\Delta x_{i t, l}^{*}=\mu_{i l}+\sum_{j=1}^{r_{i}} \gamma_{i j, l} E C M_{i, t-1}^{j}+\sum_{k=1}^{s_{i}} \varphi_{i k, l} \Delta x_{i, t-k}+\sum_{m=1}^{n_{i}} \vartheta_{i m, t} \Delta \widetilde{x}_{i, t-m}^{*}+\varepsilon_{i t, l}
$$

Where $E \mathrm{CM}_{\mathrm{i}, \mathrm{t}-1}^{\mathrm{j}}, \mathrm{j}=1,2, \ldots, \mathrm{r}_{\mathrm{i}}$ are the estimated error correction terms corresponding to the $r_{i}$ cointegrating relations found for the $\mathrm{i}^{\text {th }}$ country model and $\Delta \tilde{x}_{i, t-m}^{*}=$ $\left(\Delta \mathrm{x}^{* *}{ }_{\mathrm{it}}, \Delta\left(\mathrm{e}^{*}{ }_{\mathrm{it}}-\mathrm{p}_{\mathrm{it}}^{*}\right), \Delta \mathrm{p}_{\mathrm{t}}^{0}\right)^{\prime}$. The test for weak exogeneity is an

\footnotetext{
$1 \mathrm{y}_{\mathrm{it}}=\ln \left(\mathrm{GDP}_{\mathrm{it}} / \mathrm{CPI}_{\mathrm{it}}\right)$

$2 \pi_{\mathrm{it}}=\mathrm{p}_{\mathrm{it}}-\mathrm{p}_{\mathrm{it}-1}$ with $\mathrm{p}_{\mathrm{it}}=\ln \left(\mathrm{CPI}_{\mathrm{it}}\right)$

$3 \operatorname{Ln}\left(\mathrm{e}_{\mathrm{it}}\right)-\mathrm{p}_{\mathrm{it}}$

$4 \mathrm{q}_{\mathrm{it}}=\mathrm{Ln}\left(\mathrm{EQ}_{\mathrm{it}} / \mathrm{CPI}\right)$

$5 \rho^{\mathrm{S}}{ }_{\text {it }}=0.25 * \ln \left(1+\mathrm{R}^{\mathrm{S}}{ }_{\mathrm{it}} / 100\right)$

$6 \rho^{\mathrm{L}}{ }_{\text {it }}=0.25 * \ln \left(1+\mathrm{R}^{\mathrm{L}} \mathrm{it} / 100\right)$

7 Test results are available on request from the authors.
}

F-test of the joint hypothesis that $\gamma_{\mathrm{ij}}, \mathrm{l}=0, \mathrm{j}=1,2, \ldots, \mathrm{r}_{\mathrm{i}}$ in the above regression. The lag orders $s_{i}$ and $n_{i}$, need not be the same as the orders $\mathrm{p}_{\mathrm{i}}$ and $\mathrm{q}_{\mathrm{i}}$ of the underlying country-specific VARX* models. In our case, for this test, we imposed the order of 2 lag on all foreign variables and we assumed that $s_{i}$ $=\mathrm{p}_{\mathrm{i}}$.

\subsubsection{The Dynamic Analysis of the GVAR Model: Impulse Response Functions}

One of the important tools in the analysis of dynamical systems is the impulse response function that characterizes the possible reaction of the system to different future periods to the effect of shock variables in the model. To do so we used the general impulse response function developed by Koop, Pesaran and Potter (1996) in their non-linear model. It allows studying the dynamics of transmission of shocks. It considers the impact associated with the error of a single variable on the variable $1^{\text {th }}$ of $i^{\text {th }}$ model using their historical distributions observed. It is defined as follows:

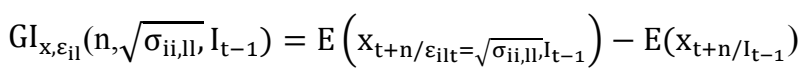

With It-1 shows all available information (t-1) and $\sigma_{\mathrm{ii}, l l}$ designates the variance of the error term $\varepsilon_{\mathrm{ii}, l l}$. This function allows studying the dynamics of the global model and estimating the magnitude of the effects of shocks to foreign variables: negative shock in equity prices in the USA, a positive shock to oil prices and negative demand shock to USA. In our study we limit the simulations to 2008 .

\section{Empirical Results}

Figures of the Annex are the response of macroeconomic variables following a negative shock to stock prices in the United States over the next two years to study the short-term macroeconomic dynamics. They include the confidence interval at $95 \%$ using the bootstrap technique.

The effect associated with a decline in demand from the United States impact is summed up in Figure 1 (in the Appendix). This shock is equivalent to a decrease of $0.4 \%$ of GDP in the United States. This will negatively impact but slowly transmitted to the GDP of Africa. Indeed, the impact will be felt only after two quarters registering a decline of $0.3 \%$. It is relatively higher comparing with shock associated with stock prices. This result suggests that the trade channel between this region and the United States is more important than the financial channel. This expected decline in GDP in these regions can be explained by the fact that the decline in GDP in the United States, will affect the demand for raw materials and their prices. In addition, it is possible that the shock reduces remittances from emigrants. This reduction led to a decline $1.15 \%$ in equity prices in the United States. Equity prices in Africa are not affected by the shock. This confirms the idea that financial integration in Africa remains relatively low.

The effect associated with a decline in demand from the United States impact is summed up in Figure 2 (in the Appendix). This shock corresponds to a $12 \%$ increase in the 
price of oil. It has a negative effect on GDP of the United States decreasing $0.08 \%$ after a quarter before leveling quickly. The impact on oil prices negatively affects all emerging countries with some exceptions.

China and Latin America recorded a significant decline which is more than twice the impact of the GDP of the United States after a year. It will be amplified for Asia, India and the emerging European countries where they recorded a decline of $0.4 \%, 0.5 \%, 1 \%$ after a quarter emerging countries. This suggests the dependence of these countries on oil is needed to manufacture all kinds of products.

In our sample, Saudi Arabia and Mexico are the two largest exporters of oil, they recorded low growth but it dissipates quickly. It should however be noted the strange behavior of the GDP of Africa, which recorded a statistically significant increase in a quarter of $0.2 \%$ which it seems difficult to interpret.

An increase in inflation is observed as a result of the oil price. The result shows a positive correlation between oil prices and inflationary pressures in most regions. In this context, the United States recorded a statistically significant positive response of $0.2 \%$, but it disappeared quickly. Similar behavior is observed for India, Asian and African emerging markets. For emerging markets, we see a reduction of interest rates in all regions. These countries pay more attention to maintain their growth than act against inflationary pressures. Finally, the exchange rate depreciates in all regions in the first two months, a logical reaction to the decline in real activity and stock prices although it is not statistically significant in all cases.

Figure 3 show that the negative impact of equity prices in the United States is equivalent to a $5 \%$ decrease in equity prices. It is immediately and negatively transmitted to African markets. However, it is not statistically significant. This is an expected result if we take into account the low level of international financial integration in this region over the greater part of the period.

This decrease was accompanied by a decline in GDP of the United States of $0.8 \%$ during the first year. For Africa, he recorded a slight decline of $0.26 \%$ during the same period. This shows the dependence of the actual activity of these regions to external financing in the United States. Indeed, the rapid capital outflows in these regions are the main cause of the decline in GDP. This can be explained by the withdrawal by foreign investors of their financial investments, qualified wealth effect theory and withdrawals of liquidity of the parent companies of multinational enterprises in these subsidiaries installed in these regions.

Regarding the dynamics of inflation following the shock, it tends to decrease in the United States recording a maximum impact of $0.14 \%$ after two quarters. It is followed by a similar reaction in the region of Africa.
Finally, the exchange rate, it is appreciated in this region amplifying the shock by slowing exports. This result can be explained by the fact that American investors affected by the fall in equity price decrease their investments and thus the demand for dollar. This causes a devaluation of the dollar against all other currencies. Other investors will have more confidence in the currency of emerging countries resulting in an appreciation in the latter. This result was observed by Dooley and Hutchison (2009) during the first phase of the subprime crisis.

\section{Conclusion}

The economic crisis triggered by the American financial crisis began in August 2007 has given rise to considerable debate about the extent of decoupling economic conditions in emerging countries and especially African countries compared to that of developed countries, and especially with the cycle United States. The objective of this work was to show how disturbances from the United States are sent to other countries of the world and especially in the African region. A new quantitative approach, the GVAR model, introduced by Pesaran, Schuermann and Weiner (2004) and developed by Dees, Di Mauro, Pesaran and Smith (2007) is used to estimate the short-term external shocks from United States on this region. The originality of this model is to examine the interdependence between domestic factors and international factors by linking each country with the rest of the global economy. Such a model is able to generate forecasts for the global economy. We also tried to identify the effect of shocks from the United States in the area of emerging Africa: the financial shock and the real shock. The results of this study showed that the United States has an important role in the transmission cycles on the region of Africa. Indeed, whatever the nature of the shock from the United States, they are persistent adverse effects on the cycles in emerging countries.

This effect is explained by the fact that the share of the United States in trade of most emerging countries is high, and even if this is not the case, these countries will be influenced by the effect of third market. In other words, a shock from the United States will be amplified over time through the diversion of their impact on other countries. The country will not only directly affect by the impact of the United States, but also indirectly through the impact of the shock on their trading partners. This is due to our model to account for these two effects.

Comparing these three shocks, it seems clear that the real shocks have more serious consequences on macroeconomic variables of Africa. The latter is characterized to a less developed capital market today and less open. 


\section{Appendix}

Table A. Countries and regions in the GVAR model

\begin{tabular}{lll}
\hline United States China Japan United Kingdom & Africa Tunisia, Egypt, Morocco South Africa. \\
Developed countries & Emerging Asian countries & Emerging Europe \\
$\begin{array}{l}\text { Canada New Zealand } \\
\text { Norway }\end{array}$ & Korea Singapore & Poland Turkey \\
$\begin{array}{l}\text { European area } \\
\text { German, France Latin America }\end{array}$ & Thailand Philippines & Indonesia \\
$\begin{array}{l}\text { Peru Colombia } \\
\text { Italy Belgium }\end{array}$ & & Rest of the world \\
Finland Netherlands & India & \\
\hline
\end{tabular}
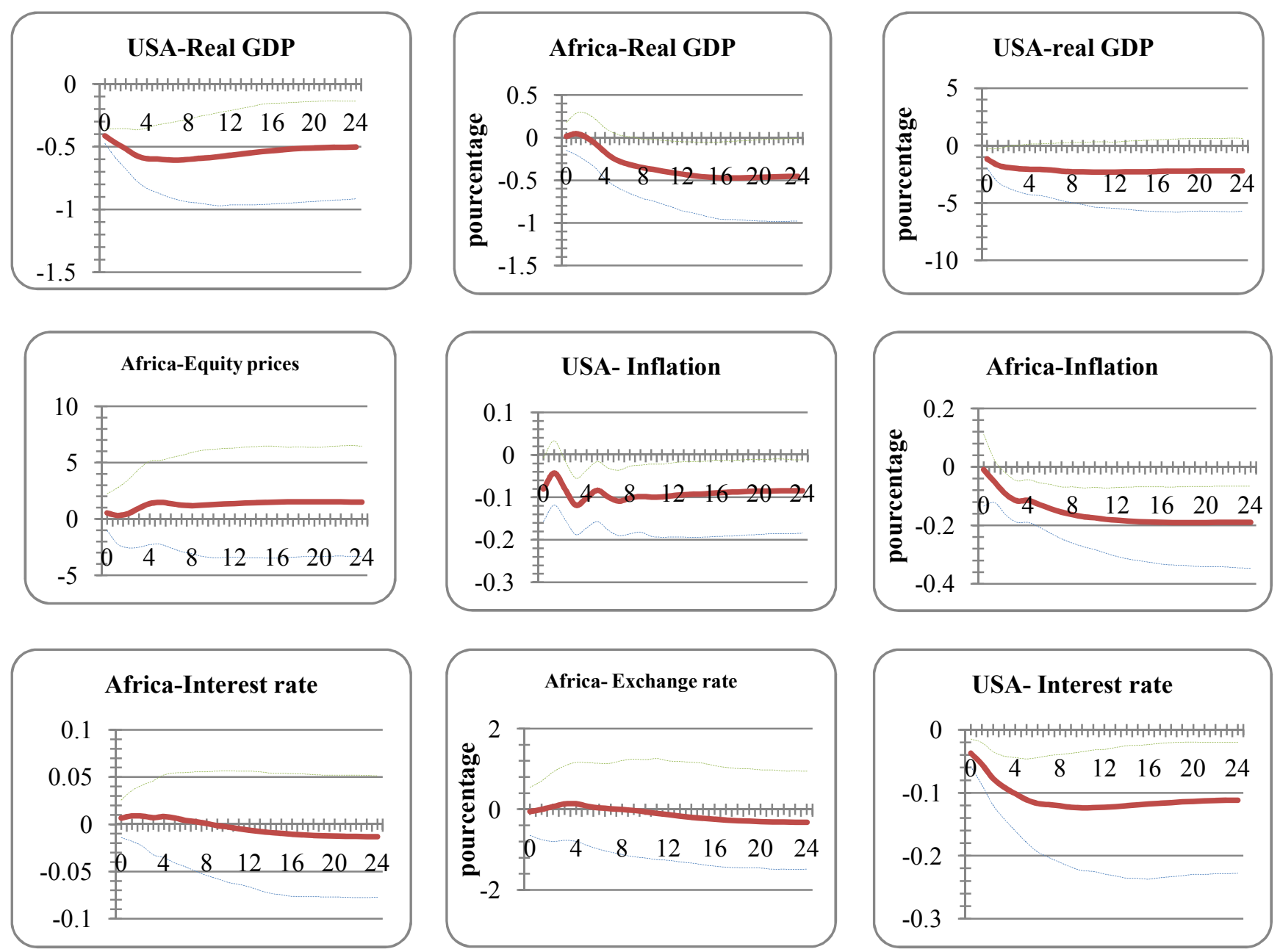

Figure 1. Impulsive functions following a negative shock of the demand in the United States on macroeconomics variables
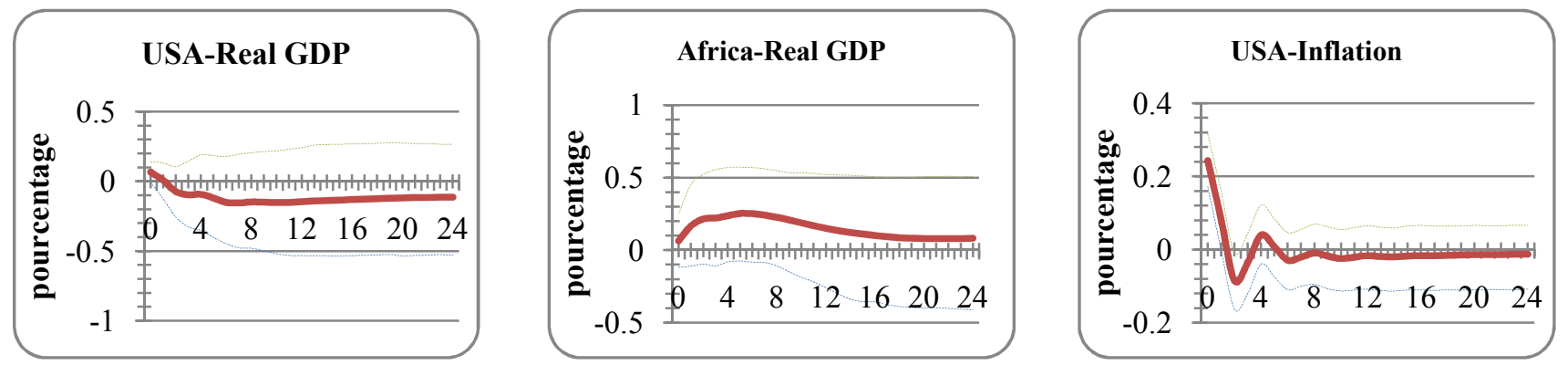

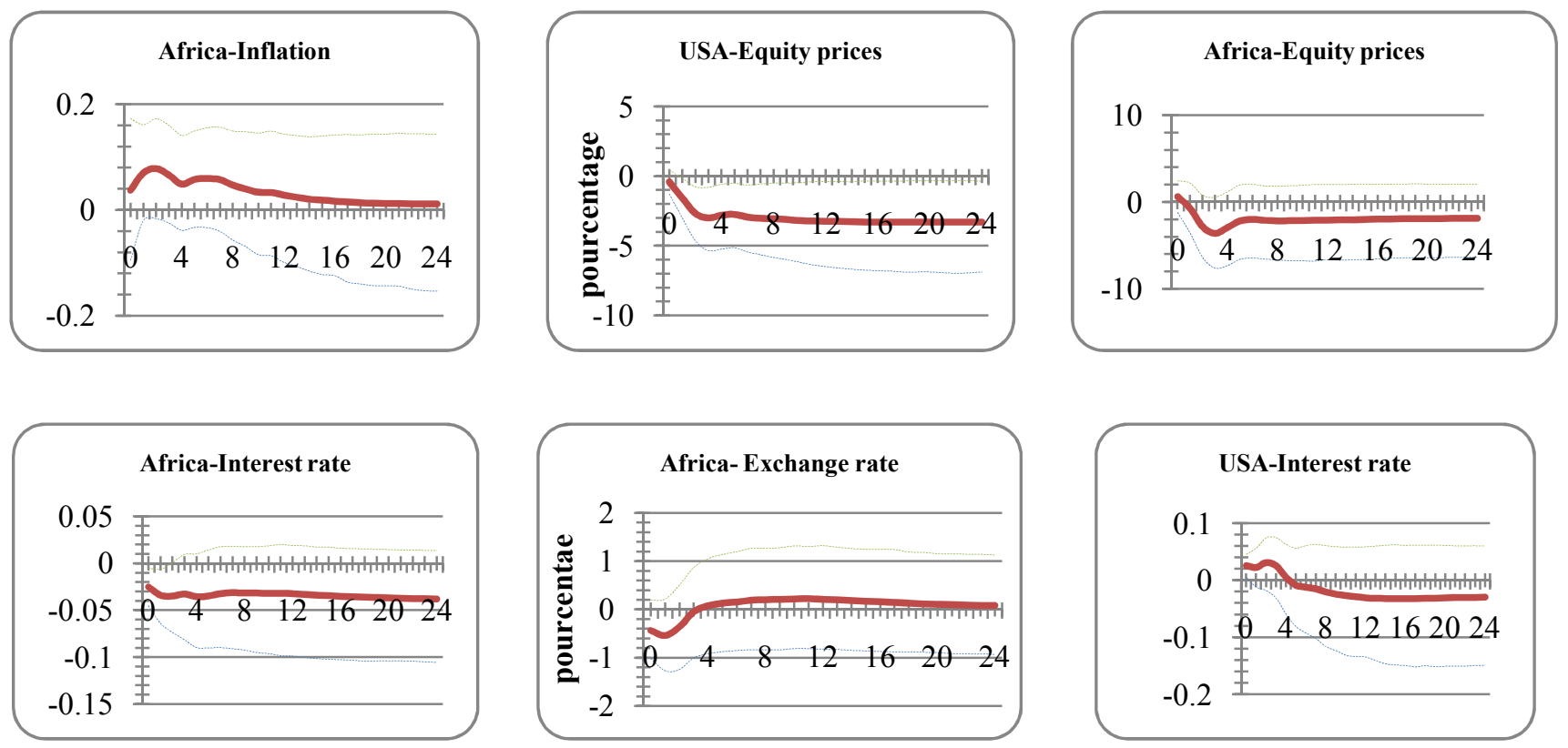

Figure 2. Impulsive functions following a negative shock to oil price in the United States on macroeconomics variables
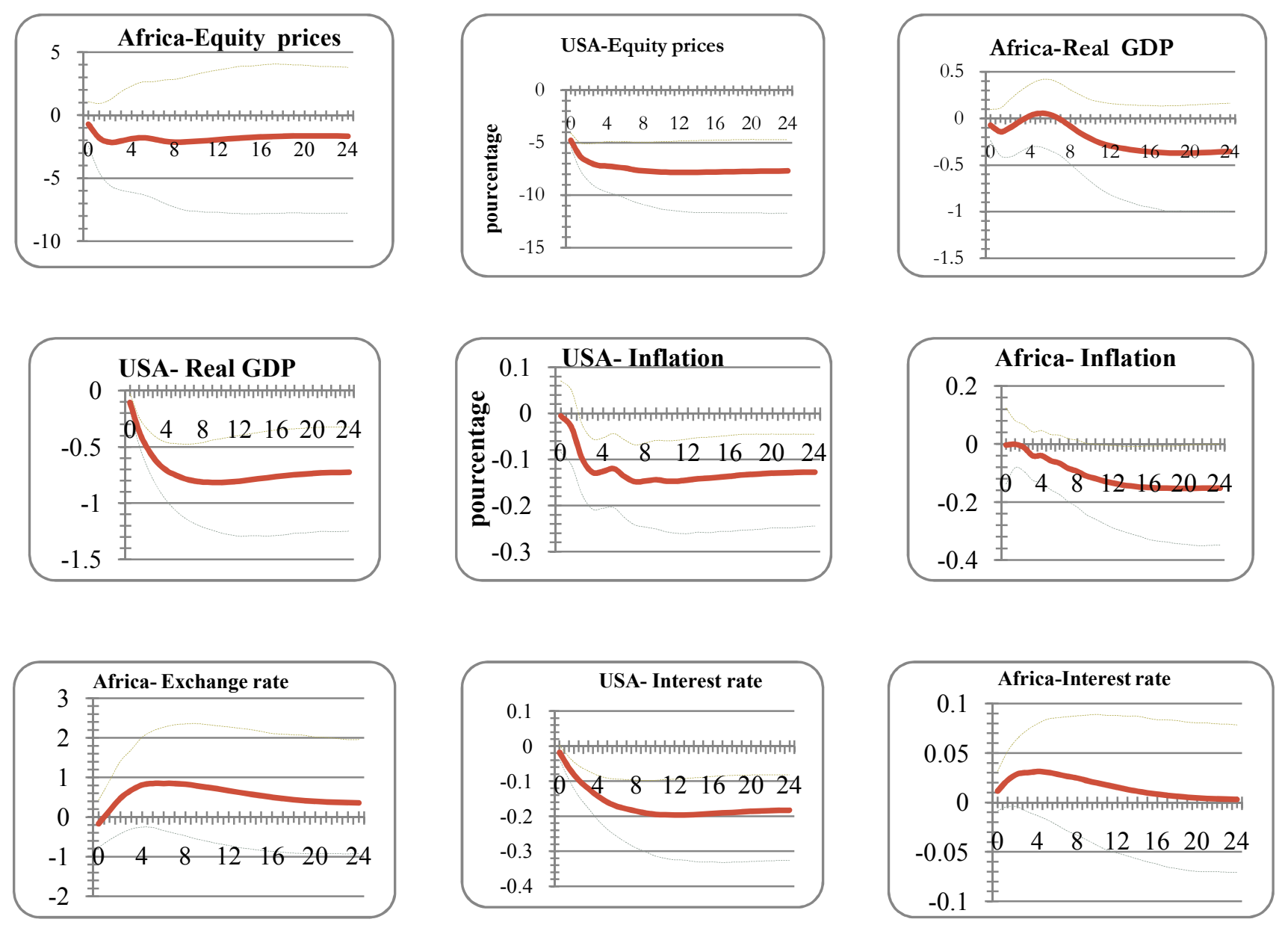

Figure 3. Impulsive functions following a negative shock to equity prices in the United States on macroeconomics variables 


\section{References}

[1] Akin, C and M.A Kose (2008) "Changing Nature of NorthSouth Linkages: Stylized Facts and Explanations" Journal of Asian Economics, Vol. 19, pp. 1-28.

[2] Altug, S. and M. Bildirici (2010) "Business Cycles Around the Globe: A Regime-Switching Approach" TÜSİAD-KOÇ University Economic Research Forum, Working Paper 100. Baxter, M. and M. Kouparitsas (2004) "Determinants of Business Cycle Comovement: A Robust Analysis" NBER Working Paper number 10725.

[3] Binder, $M$ and $M$ Gross (2013) "Regime-Switching Global Vector Autoregressive Models" European Central Bank Working Paper Series S, No 1569.

[4] Calderón, C., Chong, A. and E. Stein ( 2002) “ Trade Intensity and Business Cycle Synchronization: Are Developing Countries any Different?" Central Bank of Chile Working Paper, No.195.

[5] Canova, F. (2003) "The transmission of US shocks to Latin America" Economics Working Papers 925, Department of Economics and Business, Universitat Pompeu Fabra.

[6] Chudik, A. and M. Fratzscher (2011) "Identifying the Global Transmission of the 2007-2009 Fnancial Crisis in a GVAR Model” European Economic Review, 55, pp 325-339.

[7] Clark, T.E. and E.V. Wincoop (2001) "Borders and Business Cycles” Journal of International Economics, 55, pp 59-85.

[8] Crucini, M. J., Kose, M. A. and C. Otrok (2008) "What are the Driving Forces of International Business Cycles?" NBER Working Papers number 14380.

[9] Dees, S., Di Mauro, F., Pesaran, M., and L. Smith (2007) "Exploring the International Linkages of the Euro Area: A global VAR analysis." Journal of Applied Econometrics 22 (1), pp 1-38.

[10] Frankel, J. A and A. K. Rose (1998) "The Endogenity of the
Optimum Currency Area Criteria" Economic Journal, July, pp 1009-1025.

[11] Heathcote, J. and F. Perri, (2004) "Financial Globalization and Real Regionalization" Journal of Economic Theory, Elsevier, vol. 1191, pp 207-243.

[12] Helbling, T. and T. Bayoumi (2003) "Are They All in the Same Boat? The 2000-2001 Growth Slowdown and the G-7 Business Cycle Linkages" IMF Working Paper 03/46.

[13] Galesi, A., and S. Sgherri (2009) "Regional Financial Spillovers Across Europe" IMF Working Paper No. 09/23 (2009).

[14] Gross, M., and C. Kok (2013) "A Mixed-Cross-Section GVAR for Countries and Banks. ECB Working Paper No. 1570.

[15] Kose A., Otrok, C. and E. Prasad (2010) "Global Business Cycles: Convergence or De-coupling?" forthcoming International Economic Review.

[16] Kose, M. A., Otrok, C. and E. Prasad (2008) "Global Business Cycles: Convergence or Decoupling?'IMF Working Papers $08 / 143$.

[17] Kose, A., Prasad, E. and M. Terrones (2003) "How does Globalization Affect the Synchronization of Business Cycles?" American Economic Review 93, pp 57-62.

[18] International Monetary Fund (2007) "Spillovers and Cycles in the Global Economy" World Economic Outlook

[19] Otto, G., Voss, G. and L. Willard (2001) "Understanding OECD Output Correlations" Reserve Bank of Australia Research Discussion Paper, No. 2001-5.

[20] Pesaran, M.H., Schuermann, T. and S.C. Weiner (2004) "Modeling Regional Interdependencies Using a Global Error Correcting Macroeconomic Model" Journal of Business and Economic Statistics, 22, pp 129-162.

[21] Stock, J.H. and M.W. Watson (2005) "Understanding Changes in International Biseness Cycles Dynamics" Journal of Europeen EconomicAssociation Vol. 3, No. 5, pp 968-1006. 